Article

\title{
Characterization of a Novel PolyM-Preferred Alginate Lyase from Marine Vibrio splendidus OU02
}

\author{
Jingjing Zhuang ${ }^{1}$, Keke Zhang ${ }^{2}$, Xiaohua Liu ${ }^{2}$, Weizhi Liu ${ }^{2}{ }^{(0)}$, Qianqian Lyu ${ }^{2, *}$ \\ and Aiguo $\mathrm{Ji}$ 1,3,* \\ 1 Marine College, Shandong University, Weihai 264209, China; zhuangjj929@sdu.edu.cn \\ 2 College of Marine Life Sciences, Ocean University of China, Qingdao 266003, China; airkele@sina.com (K.Z.); \\ lingyun-1xh@163.com (X.L.); liuweizhi@ouc.edu.cn (W.L.) \\ 3 School of Pharmaceutical Sciences, Shandong University, Jinan 250012, China \\ * Correspondence: lqqdo@163.com (Q.L.); jiaiguo@sdu.edu.cn (A.J.); Tel.: +86-0532-85251693 (Q.L.); \\ $+86-0631-5688303$ (A.J.)
}

Received: 14 July 2018; Accepted: 21 August 2018; Published: 22 August 2018

\begin{abstract}
Alginate lyases are enzymes that degrade alginate into oligosaccharides which possess a variety of biological activities. Discovering and characterizing novel alginate lyases has great significance for industrial and medical applications. In this study, we reported a novel alginate lyase, AlyA-OU02, derived from the marine Vibrio splendidus OU02. The BLASTP searches showed that AlyA-OU02 belonged to polysaccharide lyase family 7 (PL7) and contained two consecutive PL7 domains, which was rare among the alginate lyases in PL7 family. Both the two domains, Aly $\mathrm{A}^{\mathrm{a}}$ and Aly $\mathrm{A}^{\mathrm{b}}$, had lyase activities, while AlyA ${ }^{\mathrm{a}}$ exhibited polyM preference, and $\mathrm{AlyA}^{\mathrm{b}}$ was polyG-preferred. In addition, the enzyme activity of AlyA ${ }^{\mathrm{a}}$ was much higher than AlyA $\mathrm{A}^{\mathrm{b}}$ at $25^{\circ} \mathrm{C}$. The full-length enzyme of AlyA-OU02 showed polyM preference, which was the same as $\mathrm{AlyA}^{\mathrm{a}}$. AlyA $\mathrm{A}^{\mathrm{a}}$ degraded alginate into di-, tri-, and tetra-alginate oligosaccharides, while $\mathrm{AlyA}^{\mathrm{b}}$ degraded alginate into tri-, tetra-, and penta-alginate oligosaccharides. The degraded products of AlyA-OU02 were similar to AlyA ${ }^{\mathrm{a}}$. Our work provided a potential candidate in the application of alginate oligosaccharide production and the characterization of the two domains might provide insights into the use of alginate of this organism.
\end{abstract}

Keywords: alginate lyase; polysaccharide lyase family 7; Vibrio splendidus OU02; polyM-preferred; characterization

\section{Introduction}

Alginate is a linear polysaccharide consisting of $\beta$-D-mannuronate (M) and $\alpha$-L-guluronate $(\mathrm{G})$ residues, arranged in varying sequences of poly $\beta$-D-mannuronate (polyM), poly $\alpha$-L-guluronate (polyG), and the heteropolymer (polyMG) [1]. It has been widely used in biomedical science and engineering, due to its low toxicity, good biocompatibility, low cost, and mild gelation [2]. Alginate now has attracted increasing attention, since it is the most abundant polysaccharide of brown algae, which is considered as the third-generation biofuel [3]. Moreover, studies have showed that alginate oligosaccharides (AOS) possess a variety of biological activities, such as antioxidant, neuroprotective, antibacterial, and antitumor [4-7]. Therefore, to research the depolymerization of alginate has great importance.

Alginate lyases are enzymes that degrade alginate into unsaturated oligosaccharides by cleaving glycosidic bonds via a $\beta$-elimination mechanism [8]. To date, a number of alginate lyases have been identified from various organisms (e.g., algae, marine mollusks, bacteria, virus, and fungi) $[2,8,9]$ and part of their structural relationships have been elucidated [10-13]. Alginate lyases are divided into polyM-specific, polyG-specific, and polyMG lyases, according to their substrate specificity [14]. According to the primary structures, alginate lyases are classified into seven polysaccharide lyase 
(PL) families, namely PL-5,6,7,14,15,17, and 18 [15]. Among the seven PL families, PL7 is the most prevalent as reported in the Carbohydrate-Active enZYmes database (http:/ / www.cazy.org/). Most of the PL7 alginate lyases belong to polyG-specific lyases, and few belong to polyM-specific lyases [12]. The substrate specificity is related with the amino acids in the highly conserved regions $[16,17]$. Commonly, the polyM-specific, polyG-specific, and polyMG alginate lyases contain QVH, QIH, and QIH in the conserved regions, respectively [17].

In this study, we reported a new polyM-preferred alginate lyase (AlyA-OU02) from the marine Vibrio splendidus OU02 which possessed two consecutive PL7 domains (Figure 1A). We cloned, expressed, and characterized AlyA-OU02 and the two PL7 domains (AlyA $\mathrm{A}^{\mathrm{a}}$ and AlyA ${ }^{\mathrm{b}}$ ), respectively. Both PL7 domains contained a highly conserved QIH sequence which was thought to indicate ployG specificity. Interestingly, it turned out that AlyA-OU02 was polyM-preferred in accordance with Aly ${ }^{\mathrm{a}}$. Our work suggested the potential applications in AOS production of AlyA-OU02, and provided insights into the use of alginate of this organism.

A

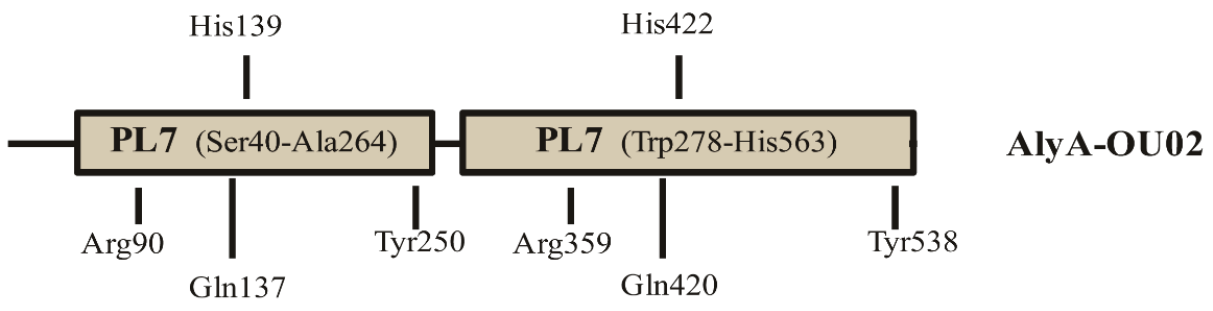

B
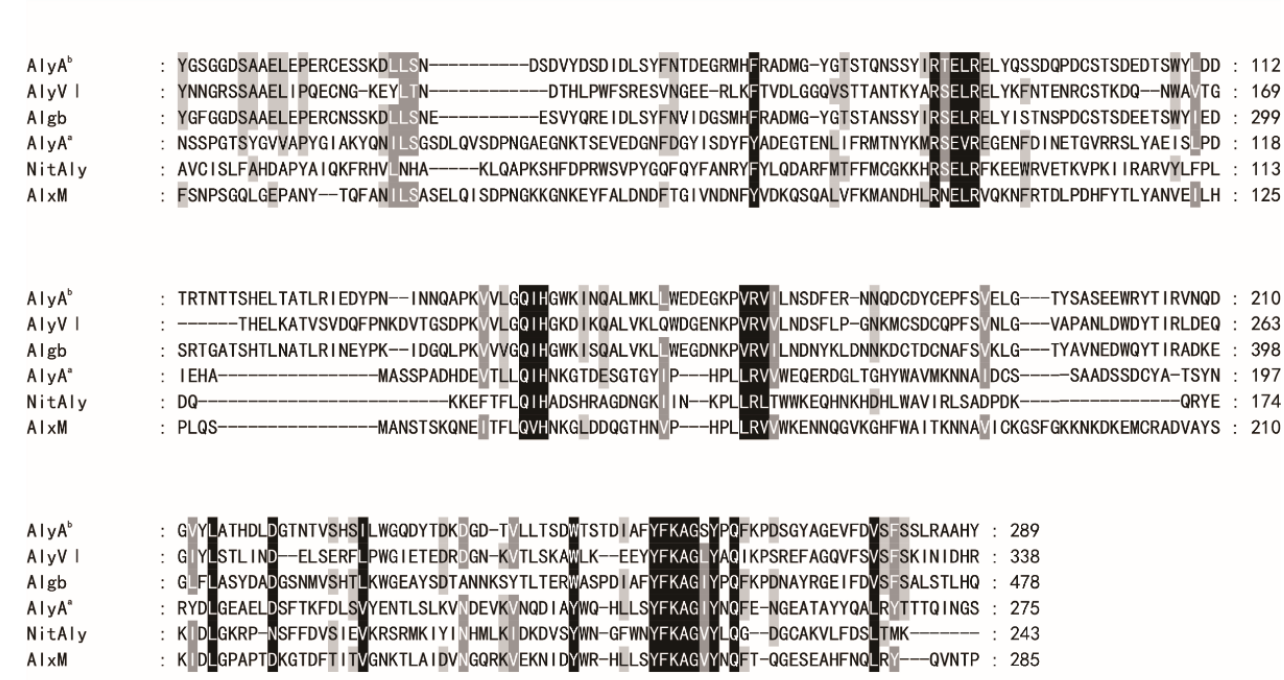

Figure 1. Sequence properties of the alginate lyase AlyA-OU02 from marine Vibrio splendidus OU02. (A) Module organization of AlyA-OU02. The two alginate_lyase 2 modules were putative catalytic domains $\left(\mathrm{Ser}^{40}\right.$ to $\mathrm{Ala}^{264}, \mathrm{Trp}^{278}$ to $\mathrm{His}^{563}$ ). The full-length protein and the two alginate_lyase 2 modules were expressed to yield the recombinant protein AlyA-OU02 (Ser ${ }^{1}$ to $\left.\operatorname{Tyr}^{564}\right)$, AlyA ${ }^{\mathrm{a}}\left(\operatorname{Ser}^{1}\right.$ to $\operatorname{Ser}^{275}$ ), and AlyA ${ }^{\mathrm{b}}$ $\left(\mathrm{Asn}^{276}\right.$ to $\left.\mathrm{Tyr}^{564}\right)$. The indicated amino acid residues were hypothesized catalytic sites. (B) Comparison of the partial amino acid sequences of $\mathrm{AlyA}^{\mathrm{a}}$ and AlyA ${ }^{\mathrm{b}}$ with PL7 alginate lyases AlyVI from Vibrio sp. QY101 (AAP45155.1), Algb from Vibrio sp. W13 (AIY22661.1), NitAly from Nitratiruptor sp. SB155-2 (BAF69299.1), AlxM from Photobacterium sp. ATCC 43367 (CAA49630.1).

\section{Results and Discussions}

\subsection{Sequence Analysis of AlyA-OU02}

The alginate lyase gene was cloned from marine Vibrio splendidus OU02, and was designated as AlyA-OU02. It consists of 1695 bp encoding 564 amino acids. The calculated molecular mass was 
$\sim 64 \mathrm{kDa}$, and the isoelectric point (PI) was 4.27. The BLASTP searches showed that AlyA-OU02 contained two alginate_lyase2 superfamily modules, and belonged to PL7 family (Figure 1A), which was similar to AlyA from Vibrio splendidus 12B01 [18]. Figure 1B showed the multiple sequence alignments of AlyA $\mathrm{A}^{\mathrm{a}}$, Aly $^{\mathrm{b}}$, and related alginate lyases of PL7 family [19-22]. Both domains contained the highly conserved regions $\mathrm{R}(\mathrm{S} / \mathrm{T}) \mathrm{E}(\mathrm{V} / \mathrm{L}) \mathrm{R}, \mathrm{QIH}$, and $\mathrm{YFKAG}(\mathrm{I} / \mathrm{S}) \mathrm{Y}$, which were necessary for substrate recognition and catalysis [23]. The putative residues involved in the catalytic reaction were pointed out in Figure 1A.

\subsection{Cloning, Expression, and Purification of Different Versions of AlyA-OU02}

To better characterize AlyA-OU02, we cloned, expressed, and purified AlyA-OU02 and its two domains, respectively. The AlyA-OU02, $\mathrm{AlyA}^{\mathrm{a}}$, and $\mathrm{AlyA}^{\mathrm{b}}$ genes were cloned into pET-32a-PreScission vector (modified by our laboratory) respectively, and expressed in the E. coli BL21 (DE3)-pET-32a-PreScission system. The enzymes were then purified by Ni-nitrilotriacetic acid agarose (Ni-NTA) affinity chromatography and analyzed by sodium dodecyl sulfate polyacrylamide gel electrophoresis (SDS-PAGE). Figure 2 showed that the molecular weights of AlyA-OU02, AlyA ${ }^{a}$, and $\mathrm{AlyA}^{\mathrm{b}}$ were approximately $65 \mathrm{kDa}, 31 \mathrm{kDa}$, and $33 \mathrm{kDa}$, which were consistent with the calculated molecular weights.

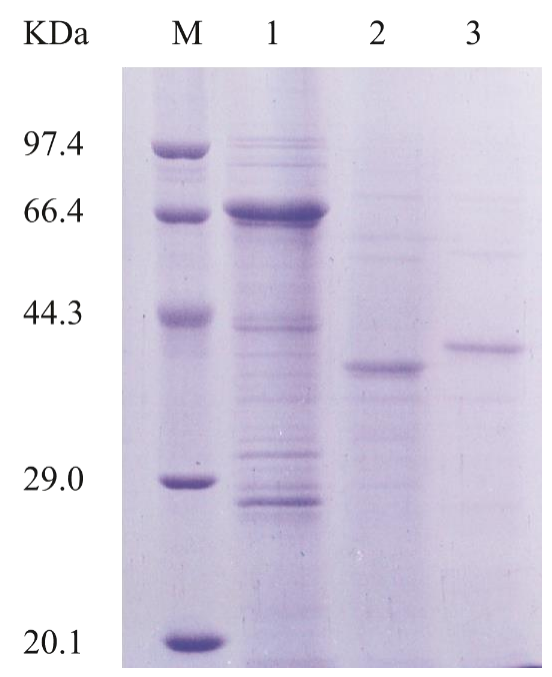

Figure 2. SDS-PAGE analysis of purified AlyA-OU02, $\mathrm{AlyA}^{\mathrm{a}}$, and $\mathrm{AlyA}^{\mathrm{b}}$. Lane $\mathrm{M}$, molecular weight markers; Lane 1, purified AlyA-OU02; Lane 2, purified AlyA ${ }^{\mathrm{a}}$; Lane 3, purified AlyA ${ }^{\mathrm{b}}$.

\subsection{Enzymatic Activity Measurements for AlyA-OU02, Aly $A^{a}$, and Aly $A^{b}$}

Alginate lyases could degrade alginate into unsaturated oligosaccharides with the formation of a double bond between $C_{4}$ and $C_{5}$ at the non-reducing terminus. The enzyme activity was measured by monitoring the increased absorbance at $235 \mathrm{~nm}$. Both domains showed alginate lyase activities, and the enzyme activity of AlyA ${ }^{\mathrm{a}}$ was much higher than AlyA ${ }^{\mathrm{b}}$ at $25^{\circ} \mathrm{C}$ (Figure 3). The enzyme activity of AlyA-OU02 was similar to AlyA ${ }^{\mathrm{a}}$. The $k_{m}$ values of AlyA-OU02, AlyA ${ }^{\mathrm{a}}$, and AlyA $\mathrm{A}^{\mathrm{b}}$ toward alginate were $3.55,4.80$, and $0.34 \mathrm{mg} / \mathrm{mL}$ respectively. The $k_{\text {cat }}$ values of AlyA-OU02, AlyA $\mathrm{A}^{\mathrm{a}}$, and AlyA ${ }^{\mathrm{b}}$ toward alginate were 630,1052 , and $42 \mathrm{~min}^{-1}$, respectively. The enzymatic kinetics assay was consistent with the enzyme activity assay.

AlyA from Vibrio splendidus 12B01 also contained two PL7 domains, and the sequence similarity between AlyA-OU02 and AlyA was 89\%, however, domain 1 of AlyA had no lyase activity [18]. We speculated the potential reason was that AlyA was purified by renaturation from inclusion bodies, and the length of AlyA (53-286) was different from AlyA ${ }^{a}$ [18]. 


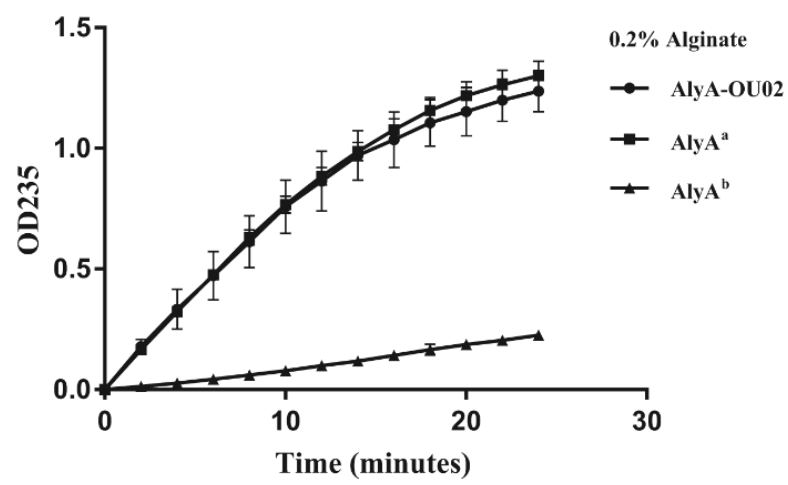

Figure 3. Enzyme activity assay of AlyA-OU02, AlyA $^{\mathrm{a}}$ and $\mathrm{AlyA}^{\mathrm{b}}$ toward alginate. The measurement was carried out in Tris- $\mathrm{HCl}$ buffer with $200 \mathrm{mM} \mathrm{NaCl}$ (pH 7.5) using $0.2 \%$ alginate as substrate.

Crystal structure of FlAlyA showed that His124 and Tyr239 in the highly conserved regions participated in the catalytic reaction [12]. Furthermore, the catalytic activities of the H124N/Y239F mutants were much lower than the wild type. We constructed H139N/Y250F mutants of AlyA ${ }^{\mathrm{a}}$ and measured the lyase activities in order to identify the catalytic residues. The purified H139N/Y250F of AlyA ${ }^{\mathrm{a}}$ were analyzed by SDS-PAGE (Figure S1). The alginate lyase activities of the mutants were undetectable, suggesting that His139 and Tyr250 were necessary for catalytic reaction of AlyA a (Figure S2).

Alginate lyases with different sequences exhibited different optimal temperatures. Most of the PL7 alginate lyases in Table 1 had maximum activity at $30-45^{\circ} \mathrm{C}$. Aly $\mathrm{A}^{\mathrm{a}}$ had maximum activity at $30^{\circ} \mathrm{C}$, while Aly $\mathrm{A}^{\mathrm{b}}$ had maximum activity at $40^{\circ} \mathrm{C}$ (Figure $4 \mathrm{~A}$ ). The different optimal temperature of the two domains might help the bacteria to better adapt to the changing environment. The alginate lyases in Table 1 had maximum activity in a $\mathrm{pH}$ range of 6.0 to 9.0. Both $\mathrm{AlyA}^{\mathrm{a}}$ and $\mathrm{AlyA}^{\mathrm{b}}$ exhibited maximum activity at $\mathrm{pH} 8.0$, which corresponded with the range (Figure $4 \mathrm{~B}$ ). The optimal temperature/pH for AlyA-OU02 was $30^{\circ} \mathrm{C} / 8.0$, the same as for AlyA ${ }^{\mathrm{a}}$. Moreover, the optimal temperature/pH for Algb [20] and ALG-5 [24] in Table 1 was also $30^{\circ} \mathrm{C} / 8.0$. Considering that the ion types in the buffer might impact the enzyme activity, we also investigated the $\mathrm{pH}$ effect in sodium phosphate buffer ( $\mathrm{pH}$ 6.0-8.0) and Tris- $\mathrm{HCl}$ buffer ( $\mathrm{pH}$ 7.0-10.0). Our results showed that sodium phosphate buffer decreased enzyme activities of AlyA-OU02, AlyA ${ }^{\mathrm{a}}$, and $\mathrm{AlyA}^{\mathrm{b}}$, compared with Tris-HCl buffer (Figure S3).

Table 1. Characterization of alginate lyases in PL7 family.

\begin{tabular}{ccccc}
\hline Protein Name & Optimal pH/Temperature $\left({ }^{\circ} \mathbf{C}\right)$ & $\begin{array}{c}\text { Conserved Region } \\
\text { QIH/QVH }\end{array}$ & Substrate Specificity & Reference \\
\hline AlyL1 & $8.6 / 40$ & QIH & PM, PG & {$[25]$} \\
Alg2A & $8.5 / 45$ & QIH & PG & {$[26]$} \\
FlAlyA & $7.8 / 55$ & QIH & PM & {$[27]$} \\
AlyPI & $7.0 / 40$ & QIH & PM, PG & {$[28]$} \\
AI-II' & $7.5 / 40$ & QIH & PM, PG, PMG & {$[29]$} \\
ALG-5 & $8.0 / 30$ & QIH & PG & {$[30]$} \\
AlyDW11 & $7.0 / 45$ & QIH & PM & {$[31]$} \\
A9MT & $7.5 / 30$ & QVH & PM & {$[24]$} \\
AlgM4 & $8.5 / 30$ & QIH & PM, PG & {$[32]$} \\
AlgNJU-03 & $7.0 / 30$ & QIH & PM, PG & {$[33]$} \\
AlgNJ-07 & $9.0 / 40$ & QVH & PM & {$[34]$} \\
rAlgSV1-PL7 & $8.0 / 45$ & QIH & PM, PMG & {$[35]$} \\
AlyH1 & $7.5 / 40$ & QIH & PG & {$[36]$} \\
Aly2 & $6.0 / 40$ & QIH & PM, PG & {$[37]$} \\
Algb & $8.0 / 30$ & QVH & PM & {$[38]$} \\
PyAly & $8.0 / 35$ & QIH & PM, PG & {$[19]$} \\
AlyVI & $7.5 / 40$ & QIH & PM & {$[21]$} \\
NitAly & $6.0 / 70$ & QVH & PM & {$[22]$} \\
AlxM & $-/-$ & &
\end{tabular}


A

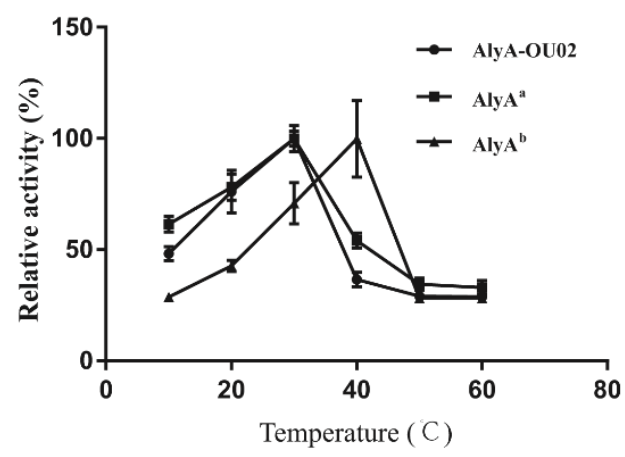

B

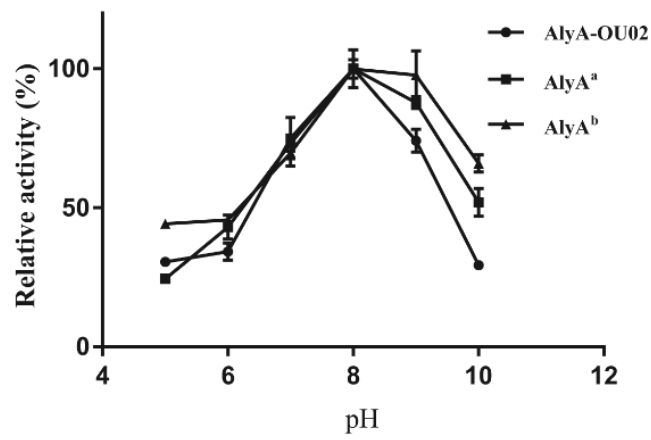

Figure 4. Effects of temperature and $\mathrm{pH}$ on enzyme activities of AlyA-OU02, AlyA ${ }^{\mathrm{a}}$, and AlyA ${ }^{\mathrm{b}}$. (A) Optimal temperatures of the enzymes were determined in Tris- $\mathrm{HCl}$ buffer with $200 \mathrm{mM} \mathrm{NaCl}$ ( $\mathrm{pH} 7.5)$ at different temperatures. (B) Optimal $\mathrm{pH}$ of the enzymes was determined at $25{ }^{\circ} \mathrm{C}$ in NaAc-HAc buffer ( $\mathrm{pH}$ 5-6) and Tris-HCl buffer ( $\mathrm{pH} 7-10)$.

To assess the thermostabilities of AlyA-OU02 and its two domains, the enzymes were incubated in Tris- $\mathrm{HCl}$ buffer at different temperatures for $1 \mathrm{~h}$. The enzyme activities were assayed using alginate as the substrate. As shown in Figure 5, the activity of AlyA ${ }^{\mathrm{a}}$ remained unchanged, while AlyA ${ }^{\mathrm{b}}$ retained $40 \%$ activity after incubation at $30^{\circ} \mathrm{C}$ for $1 \mathrm{~h}$. The stability of AlyA-OU02 decreased with increasing temperature, and retained $50 \%$ activity after incubation at $30{ }^{\circ} \mathrm{C}$ for $1 \mathrm{~h}$. All the three enzymes were inactive after incubation at $50{ }^{\circ} \mathrm{C}$. Our findings suggested that $\mathrm{AlyA}^{\mathrm{a}}$ exhibited more thermostability compared to AlyA ${ }^{\mathrm{b}}$ and AlyA-OU02.

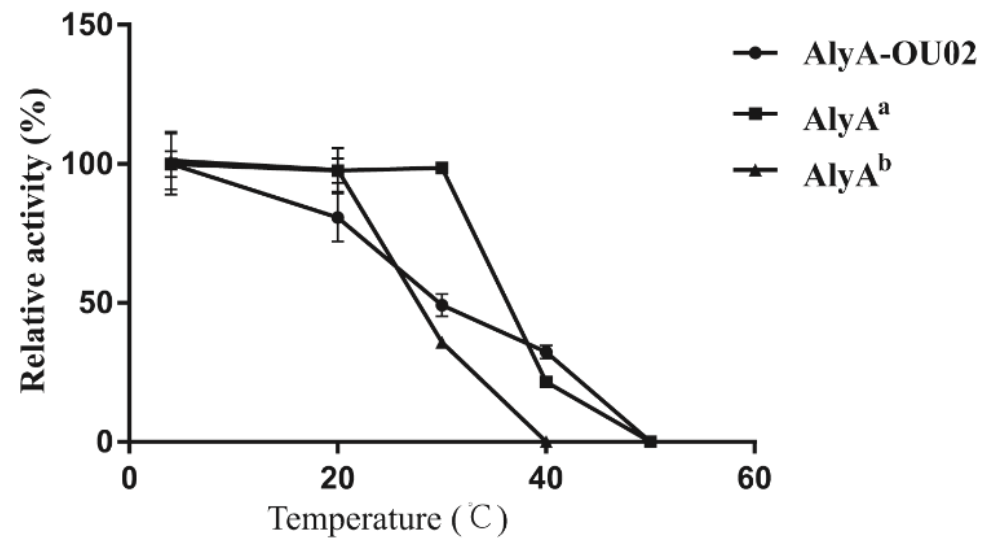

Figure 5. Thermostabilities of AlyA-OU02, AlyA $^{\mathrm{a}}$, and AlyA ${ }^{\mathrm{b}}$.

The activities of alginate lyases might be affected by metal ions, since various organisms survived and evolved in various environments. We first examined the effects of $\mathrm{NaCl}$ on the enzymatic activities. As shown in Figure 6A, $200 \mathrm{mM} \mathrm{NaCl}$ could effectively enhance the activities of AlyA-OU02 and AlyA $^{\mathrm{a}}$, while moderately affecting Aly ${ }^{\mathrm{b}}$. Certain alginate lyases could be activated by $\mathrm{NaCl}$, but were not resistant to high concentrations of $\mathrm{NaCl}$, such as AlyH1 [36] and AlgA [39]. AlyA-OU02, AlyA and $\mathrm{AlyA}^{\mathrm{b}}$ all exhibited high salt tolerance, which was analogous to AlgM4 from marine bacterium Vibrio weizhoudaoensis M0101 [32]. The effects of chelating agent and other metal ions on AlyA-OU02, $\mathrm{AlyA}^{\mathrm{a}}$, and $\mathrm{AlyA}^{\mathrm{b}}$ activities were studied in the absence of $\mathrm{NaCl}$. As shown in Figure $6 \mathrm{~B}-\mathrm{D}, \mathrm{Ca}^{2+}$ showed little effect on the enzymatic activities. Similarly to rAlgSV1-PL7 [35], AlyA-OU02, AlyA a , and AlyA ${ }^{\mathrm{b}}$ could be activated by $\mathrm{Mg}^{2+}$. Besides, enzymatic activities of AlyA-OU02 and AlyA ${ }^{\mathrm{a}}$ were 
inhibited by the chelating agent ethylenediaminetetraacetic acid (EDTA), indicating that AlyA-OU02 and Aly $\mathrm{A}^{\mathrm{a}}$ might be ion-dependent alginate lyases.

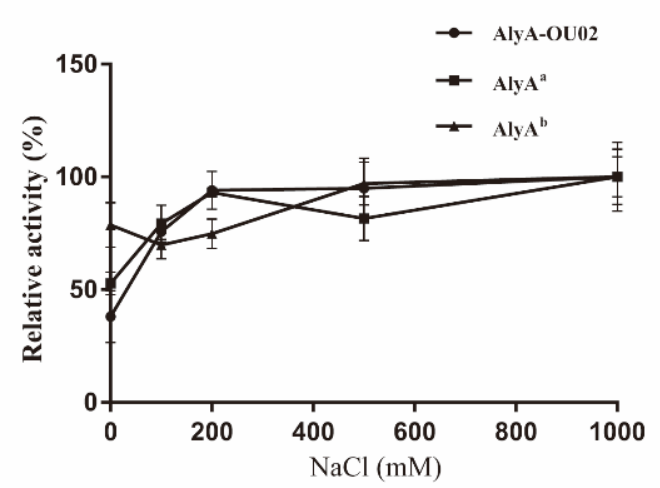

$\mathrm{C}$

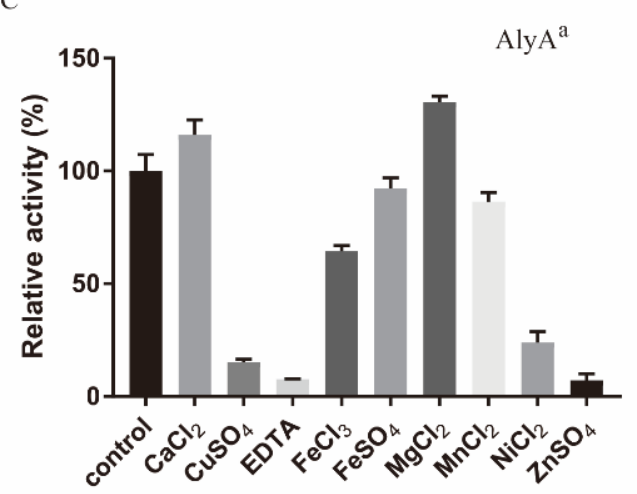

B

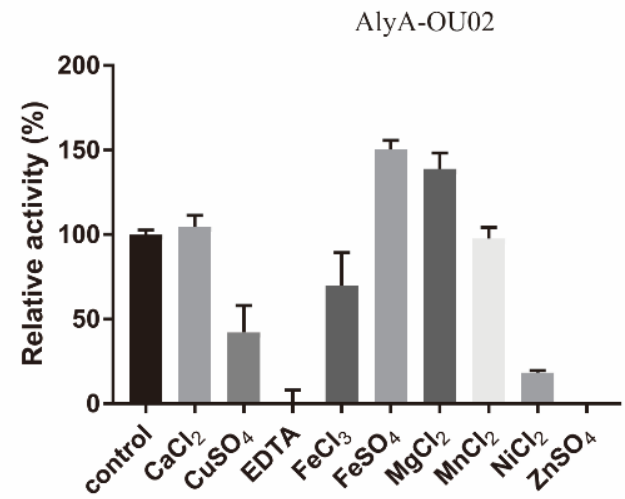

D

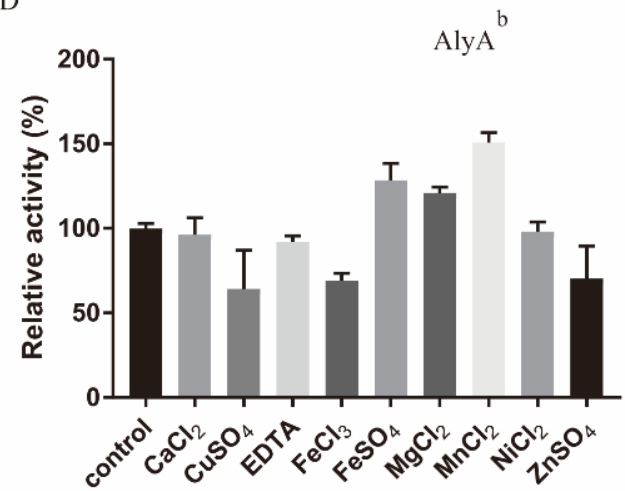

Figure 6. Effects of $\mathrm{NaCl}$ and metal ions on enzymatic activities of AlyA-OU02, AlyA ${ }^{\mathrm{a}}$, and $\mathrm{AlyA}^{\mathrm{b}}$. (A) Influence of the concentration of $\mathrm{NaCl}$. (B) Influence of the metal ions on AlyA-OU02. (C) Influence of the metal ions on AlyA ${ }^{a}$. (D) Influence of the metal ions on AlyA ${ }^{b}$. The enzymatic activity without metal ions served as the control, and the enzymatic activity was designated as $100 \%$.

To determine the substrate specificity, $0.2 \%$ alginate, polyG, and polyM were used as the substrates to study the enzyme activities. The relative activities of Aly $\mathrm{A}^{\mathrm{a}}$ toward alginate, polyG, and polyM were $48.1 \% \pm 2.2 \%, 20.0 \% \pm 2.2 \%$, and $100.0 \% \pm 6.2 \%$, respectively, indicating that Aly ${ }^{\mathrm{a}}$ was a polyM-preferred alginate lyase (Figure $7 \mathrm{~A}$ ). $\mathrm{AlyA}^{\mathrm{b}}$ showed slight polyG preference (Figure $7 \mathrm{~B}$ ). The relative activities of AlyA-OU02 toward alginate, polyG, and polyM, were $60.0 \% \pm 8.7 \%, 20.7 \% \pm 0.4 \%$, and $100.0 \% \pm 9.1 \%$, respectively (Figure $7 \mathrm{C}$ ), which was similar to AlyA $\mathrm{A}^{\mathrm{a}}$. The specific activities of AlyA-OU02, AlyA $\mathrm{A}^{\mathrm{a}}$, and $\mathrm{AlyA}^{\mathrm{b}}$ toward alginate, polyG, and polyM are shown in Table 2. The substrate specificities of PL7 alginate lyases were related with the protein sequences in the conserved regions [17]. Crystal structures and sequence analyses showed that the three conserved regions in PL7 family formed the cavity composed of a jelly roll $\beta$-sandwich structure, which was assumed to bind to a suitable substrate [24]. The conserved amino acids are thought to be pivotal in catalytic activity or folding of the structure. Recent studies have revealed that the polyM-specific, polyG-specific, and polyMG alginate lyases contained QVH, QIH, and QIH in the conserved regions, respectively [17]. As shown in Table 1, the alginate lyases that showed activities toward polyG and polyM contained QIH in the conserved region, with the exception of rAlgSV1-PL7 [35]. A9mT and PyAly contained QVH and were polyM-specific [24,38]. The polyG-specific enzymes, such as Alg2A, ALG-5, and Aly2, all contained QIH sequence [26,30,37]. Contrary to this accepted rule, Aly $^{\mathrm{a}}$ was active toward polyM, containing QIH sequence which was similar to FlAlyA and AlyDW11 [27,31]. 
A

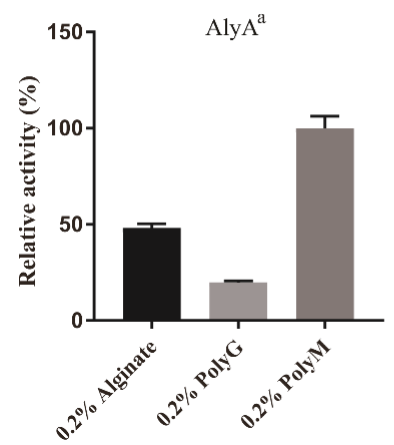

B

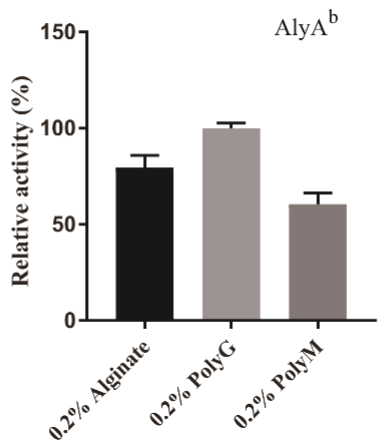

C

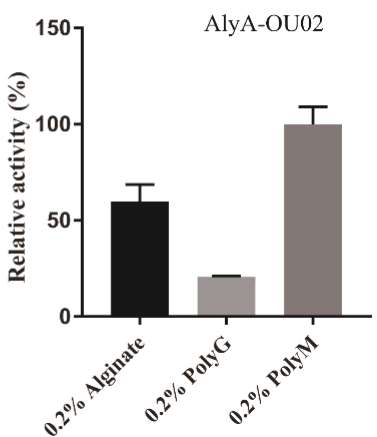

Figure 7. Substrate specificities of AlyA-OU02, $\operatorname{AlyA}^{\mathrm{a}}$, and $\mathrm{AlyA}^{\mathrm{b}}$. (A) Relative enzyme activities of AlyA $^{\mathrm{a}}$ toward alginate, polyM, and polyG. (B) Relative enzyme activities of Aly $\mathrm{A}^{\mathrm{b}}$ toward alginate, polyM, and polyG. (C) Relative enzyme activities of AlyA-OU02 toward alginate, polyM, and polyG.

Table 2. Specific activities of AlyA-OU02, $\mathrm{AlyA}^{\mathrm{a}}$, and $\mathrm{AlyA}^{\mathrm{b}}$ toward alginate, polyG, and polyM.

\begin{tabular}{cccc}
\hline Specific Activity (U/mg) & Alginate & PolyG & PolyM \\
\hline AlyA-OU02 & 119 & 41 & 198 \\
AlyA $^{\mathrm{a}}$ & 252 & 104.5 & 520 \\
AlyA $^{\mathrm{b}}$ & 24 & 33 & 15 \\
\hline
\end{tabular}

\subsection{Thin-Layer Chromatography Analysis of the Degradation Products}

To investigate the action modes of AlyA-OU02, $\mathrm{AlyA}^{\mathrm{a}}$, and AlyA ${ }^{\mathrm{b}}$, the degradation products of alginate, polyG, and polyM after $1 \mathrm{~h}$ were analyzed by thin-layer chromatography (TLC). As shown in Figure 8, Aly $\mathrm{A}^{\mathrm{a}}$ degraded alginate and polyM into di-, tri-, and tetra-oligosaccharides, and trisaccharide was the main product. The products patterns of AlyA-OU02 were similar to AlyA ${ }^{\mathrm{a}}$. For AlyA ${ }^{\mathrm{b}}$, tri-, tetra-, and penta-oligosaccharides were the main hydrolysis products, and Aly $\mathrm{A}^{\mathrm{b}}$ had limited activity toward polyM. The results were consistent with the enzymatic assays. We also analyzed the overnight products of alginate, polyG, and polyM, and the product patterns remained the same (Figure S4). This indicated that AlyA-OU02 and AlyA ${ }^{a}$ might be potential tools for preparation of lower molecular weight polyM products which have wide pharmaceutical applications.

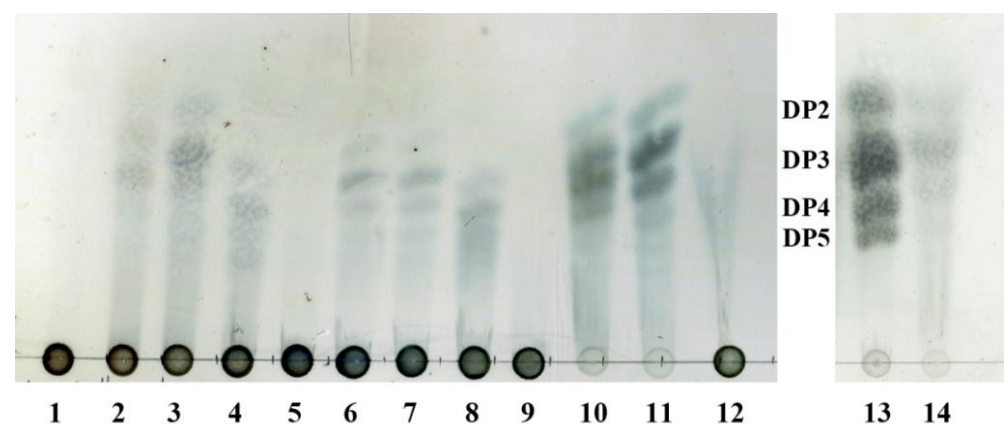

Figure 8. TLC analysis of the hydrolytic products of AlyA-OU02, $\mathrm{AlyA}^{\mathrm{a}}$, and $\mathrm{AlyA}^{\mathrm{b}}$. Solutions of $0.2 \%$ $(w / v)$ alginate, polyG, and polyM were each incubated with $5 \mathrm{uM}$ AlyA-OU02, $\mathrm{AlyA}^{\mathrm{a}}$, and AlyA ${ }^{\mathrm{b}}$, respectively, at $25^{\circ} \mathrm{C}$ for $1 \mathrm{~h}$. Lane 1: alginate; lane 2-4: hydrolytic products of AlyA-OU02, $\mathrm{AlyA}^{\mathrm{a}}$, and $\mathrm{AlyA}^{\mathrm{b}}$ toward alginate; lane 5: polyG; lane 6-8: hydrolytic products of AlyA-OU02, $\mathrm{AlyA}^{\mathrm{a}}$, and $\mathrm{AlyA}^{\mathrm{b}}$ toward polyG; lane 9: polyM; lane 10-12: hydrolytic products of AlyA-OU02, $\mathrm{AlyA}^{\mathrm{a}}$, and $\mathrm{AlyA}^{\mathrm{b}}$ toward polyM; lane 13: DP2, DP3, DP4, and DP5 mean the alginate disaccharide, trisaccharide, tetrasaccharide, and pentasaccharide, respectively; lane 14: hydrolytic products of Aly ${ }^{\mathrm{a}}$ toward polyM. 


\section{Materials and Methods}

\subsection{Materials}

Alginate was purchased from Shanghai Yuanye co., Ltd. The alginate viscosity is $4500 \mathrm{cP}$ at $2 \%(w / v)$ concentration at $25{ }^{\circ} \mathrm{C}$. The $\mathrm{M} / \mathrm{G}$ ratio of alginate is 0.6 as determined by NMR analysis. PolyG and polyM were prepared according to the reference [10]. Other chemicals and reagents used in this study were of analytical grade.

\subsection{Sequence Analysis of AlyA-OU02}

For functional annotation, the BLAST algorithm on the National Center for Biotechnology Information server (http: / / www.ncbi.nlm.nih.gov) was used to analyze the similarity of the amino acid sequences. Molecular weights of the enzymes were estimated by the peptide mass tool on the ExPASY server of the Swiss Institute of Bioinformatics (http:/ / swissmodel.expasy.org/). Multiple sequence alignments were performed by MEGA version 5.05 .

\subsection{Construction of Expression Vectors}

The gene encoding AlyA-OU02 was amplified from genomic Vibrio splendidus OU02 DNA (unpublished data) using the forward primer (5'-CGGAATTCAGTAGTTCAAATAGCTCGACTG-3') and reverse primer (5'-CCGCTCGAGTCAATAGTGTGCCGCTCTAAGAG-3'). The AlyA ${ }^{\text {a }}$ gene was amplified using the forward primer (5'-GGAATTCAGTAGTTCAAATAGCTCGACTG-3') and reverse primer (5'-CCGCTCGAGTTATGACCCATTGATTTG- $\left.3^{\prime}\right)$. The AlyA ${ }^{\mathrm{b}}$ gene was amplified using the forward primer ( $5^{\prime}$-GGAATTCAACGATTGGGACATTAATGATTG-3') and reverse primer (5'-CCGCTCGAGTTAATAGTGTGCCGCTCTAAG-3'). DNA amplification products were cloned into the expression vector pET-32a-PreScission. The recombinant plasmids were transformed into E. coli BL21 (DE3) cells. DNA sequencing was used to confirm the integrities of the nucleotide sequences of newly constructed plasmids.

Site-directed mutagenesis was conducted using the QuikChange Site-Directed Mutagenesis Kit (Aglient Technologies, CA, USA). For generation of the H139N mutant, the primers used in this study were forward primer (5'-GTGACGTTGCTGCAGATAAACAATAAGGGGACTGATG-3') and reverse primer (5'-CATCAGTCCCCTTATTGTTTATCTGCAGCAACGTCAC-3'). For the Y250F mutant, the primers used in this study were forward primer (5'-GCTACTTCAAAGCGGGTATCTTTAACCA“ATTTGAGAATGGTG-3”) and reverse primer (5'-CACCATTCTCAAATTGGTTAAAGATACCCGCTTTGAAGTAGC-3').

\subsection{Expression and Purification of AlyA-OU02, Aly $A^{a}$ and AlyA}

E. coli BL21 (DE3) cells harboring the plasmid were initially cultured in LB broth containing ampicillin at $37^{\circ} \mathrm{C}$. When the cell density reached an $\mathrm{A}_{600}$ value of $0.6,0.1 \mathrm{mM}$ (final concentration) isopropyl $\beta$-D-1-thiogalactopyranoside was used to induce enzyme expression for $8 \mathrm{~h}$ at $16{ }^{\circ} \mathrm{C}$. The cells were harvested by centrifugation $\left(1500 \times g, 30 \mathrm{~min}, 4^{\circ} \mathrm{C}\right)$ and sonicated in $20 \mathrm{mM}$ Tris, $500 \mathrm{mM} \mathrm{NaCl}$ ( $\mathrm{pH}$ 7.5). The lysates were clarified by centrifugation $\left(20,000 \times \mathrm{g}, 30 \mathrm{~min}, 4{ }^{\circ} \mathrm{C}\right)$. The supernatant containing soluble proteins was loaded onto a Ni-NTA column. The samples were eluted with a linear gradient of 10-500 mM imidazole. The molecular mass and the purities of the enzymes were analyzed by $12 \%$ SDS-PAGE.

\subsection{Enzymatic Activity Assay}

To determine the activities of the alginate lyases, $20 \mu \mathrm{L}$ diluted enzyme $(5 \mu \mathrm{M})$ was added to $180 \mu \mathrm{L}$ substrate solution containing $0.2 \%(w / v)$ substrate, $50 \mathrm{mM}$ Tris- $\mathrm{HCl}$, and $200 \mathrm{mM} \mathrm{NaCl}(\mathrm{pH} 7.5)$. After incubation at $25{ }^{\circ} \mathrm{C}$ for $10 \mathrm{~min}$, alginate lyase activity was determined by measuring the increased absorbance at $235 \mathrm{~nm}$ of the reaction buffer. One unit was defined as the amount of enzyme required to increase the absorbance at $235 \mathrm{~nm}$ by 0.1 per $\min [40]$. 
For kinetic analysis, the substrate concentrations varied from $0.33 \mathrm{mg} / \mathrm{mL}$ to $4 \mathrm{mg} / \mathrm{mL}$. The reactions ( $200 \mu \mathrm{L}$ for each assay) were carried out in $50 \mathrm{mM}$ Tris- $\mathrm{HCl}(\mathrm{pH} 7.5)$ with $200 \mathrm{mM}$ $\mathrm{NaCl}$ at $25^{\circ} \mathrm{C}$ for $10 \mathrm{~min}$. After incubation, $200 \mu \mathrm{L}$ of dinitrosalicylic acid was added to the reaction mixture, followed by heating at $100{ }^{\circ} \mathrm{C}$ for $5 \mathrm{~min}$ and centrifugation. The absorbance at $520 \mathrm{~nm}$ of the resulting supernatant was measured.

To determine the effects of temperature on enzyme activities, the reactions ( $200 \mu \mathrm{L}$ for each assay) were carried out in $50 \mathrm{mM}$ Tris- $\mathrm{HCl}(\mathrm{pH} 7.5)$ with $200 \mathrm{mM} \mathrm{NaCl}$ at different temperatures $\left(10-60{ }^{\circ} \mathrm{C}\right)$ for $10 \mathrm{~min}$, with alginate as substrate. After incubation, $200 \mu \mathrm{L}$ of dinitrosalicylic acid was added to the reaction mixture, followed by heating at $100{ }^{\circ} \mathrm{C}$ for $5 \mathrm{~min}$ and centrifugation. The absorbance at $520 \mathrm{~nm}$ of the resulting supernatant was measured. To determine the effects of $\mathrm{pH}$ on enzyme activities, the reactions ( $200 \mu \mathrm{L}$ for each assay) were carried out in buffers with different $\mathrm{pH}$ values, including NaAC-HAC buffer ( $\mathrm{pH}$ 5.0-6.0) and Tris-HCl buffer ( $\mathrm{pH} 7.0-10.0$ ) at $25^{\circ} \mathrm{C}$ for $10 \mathrm{~min}$, with alginate as substrate. The increased absorbance at $520 \mathrm{~nm}$ was measured.

To determine the thermostabilities, the enzyme solutions were incubated at various temperatures for $1 \mathrm{~h}$. The reactions ( $200 \mu \mathrm{L}$ for each assay) were carried out in $50 \mathrm{mM}$ Tris- $\mathrm{HCl}(\mathrm{pH}$ 7.5) with $200 \mathrm{mM} \mathrm{NaCl}$ at $25^{\circ} \mathrm{C}$ for $10 \mathrm{~min}$ with $0.2 \%(w / v)$ alginate as substrate. After incubation, $200 \mu \mathrm{L}$ of dinitrosalicylic acid was added to the reaction mixture, followed by heating at $100{ }^{\circ} \mathrm{C}$ for $5 \mathrm{~min}$ and centrifugation. The absorbance at $520 \mathrm{~nm}$ of the resulting supernatant was measured.

The effects of metal ions on enzyme activities were carried out by incubating enzymes at $4{ }^{\circ} \mathrm{C}$ for $1 \mathrm{~h}$ in the presence of various metal ions $(1 \mathrm{mM})$ or EDTA $(5 \mathrm{mM})$ in $50 \mathrm{mM}$ Tris-HCl buffer (pH 7.5). The reactions ( $200 \mu \mathrm{L}$ for each assay) were carried out in $50 \mathrm{mM}$ Tris- $\mathrm{HCl}(\mathrm{pH} 7.5)$ at $25^{\circ} \mathrm{C}$ for $10 \mathrm{~min}$ with alginate as substrate. The increased absorbance at $235 \mathrm{~nm}$ was measured.

To study the substrate specificities, the reactions ( $200 \mu \mathrm{L}$ for each assay) were carried out in $50 \mathrm{mM}$ Tris- $\mathrm{HCl}(\mathrm{pH} 7.5)$ with $200 \mathrm{mM} \mathrm{NaCl}$ at $25^{\circ} \mathrm{C}$ for $10 \mathrm{~min}$, using $0.2 \%(w / v)$ alginate, polyM, and polyG separately as substrates. The increased absorbance at $235 \mathrm{~nm}$ was measured.

\subsection{TLC Analysis of the Degradation Products}

To analyze the oligosaccharides produced by the enzymes, $20 \mu \mathrm{L}$ diluted enzyme $(5 \mu \mathrm{M})$ was added to $180 \mu \mathrm{L}$ substrate solution containing $0.2 \%(w / v)$ substrate, $50 \mathrm{mM}$ Tris- $\mathrm{HCl}$, and $200 \mathrm{mM}$ $\mathrm{NaCl}$ (pH 7.5). After incubation at $25^{\circ} \mathrm{C}$ for $1 \mathrm{~h}$ or $12 \mathrm{~h}$, the reaction buffer was boiled for $5 \mathrm{~min}$, and analyzed by TLC with the solvent system (1-butanol/formic acid/water 4:6:1). The TLC plate was sprayed using $10 \%(v / v)$ sulfuric acid in ethanol, and then heated at $130{ }^{\circ} \mathrm{C}$ for $5 \mathrm{~min}$.

\section{Conclusions}

In this study, we reported a new alginate lyase derived from the marine Vibrio splendidus OU02. AlyA-OU02 was characterized as a novel PL7 alginate lyase containing two PL7 domains. Surprisingly, both of the two domains showed alginate lyase activities. Although both domains contained QIH sequence in the conserved regions, which was thought to be polyG-specific, AlyA-OU02 turned out to be polyM-preferred. The two domains exhibited different enzymatic properties. The optimal temperature, $\mathrm{pH}$, metal ions effects, and degradation patterns of AlyA-OU02 were similar to AlyA ${ }^{\mathrm{a}}$. The putative reason was that the enzyme activity of $\mathrm{AlyA}^{\mathrm{a}}$ was much higher than $\mathrm{AlyA}^{\mathrm{b}}$ at $25^{\circ} \mathrm{C}$. Further work will be focused on obtaining crystals of the enzymes to elucidate the catalytic mechanism of AlyA-OU02.

Supplementary Materials: The following are available online at http:/ / www.mdpi.com/1660-3397/16/9/295/s1, Figure S1: SDS-PAGE analysis of purified H139N/Y250F mutants of AlyA ${ }^{\mathrm{a}}$. Lane 1, H139 mutant of AlyA ${ }^{\mathrm{a}}$; Lane 2, Y250F mutants of AlyA ${ }^{\mathrm{a}}$; Lane M, molecular weight markers, Figure S2: Enzyme activities of H139 and Y250F mutants of AlyA ${ }^{\mathrm{a}}$. The relative enzyme activity of AlyA ${ }^{\mathrm{a}}$ was designated as $100 \%$, Figure S3: Effects of $\mathrm{pH}$

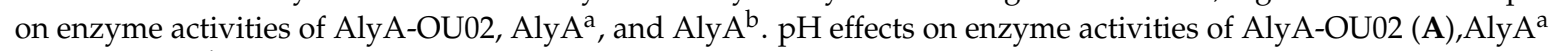
(B), and $\mathrm{AlyA}^{\mathrm{b}}(\mathrm{C})$ in sodium phosphate buffer ( $\mathrm{pH}$ 6.0-8.0) and Tris-HCl buffer ( $\left.\mathrm{pH} 7.0-10.0\right)$, Figure S4: TLC analysis of the hydrolytic products of AlyA-OU02, $\mathrm{AlyA}^{\mathrm{a}}$, and AlyA ${ }^{\mathrm{b}}$. Analysis of the hydrolytic products of AlyA-OU02 (lane 1-3), AlyA (lane 4-6), and AlyA ${ }^{\mathrm{b}}$ (lane 7-9) for $12 \mathrm{~h}$ with either alginate, polyG, and polyM 
as substrates. Lane 10, DP2, DP3, DP4, and DP5 mean the alginate disaccharide, trisaccharide, tetrasaccharide, and pentasaccharide, respectively.

Author Contributions: Q.L. and J.Z. conceived and designed the experiments; J.Z. and K.Z. performed the experiments; K.Z. and X.L. analyzed the data; W.L. contributed reagents/materials/analysis tools; J.Z. wrote the paper; W.L. and A.J. edited the paper.

Funding: This work was supported by the Shandong Provincial Natural Science Foundation, China (ZR2017PH053), the Shandong Provincial Natural Science Foundation, China (ZR2016DB17), the China Postdoctoral Science Foundation (2017M612297), and the National Natural Science Foundation of China (41706151).

Conflicts of Interest: The authors declare no conflict of interest.

\section{References}

1. Pawar, S.N.; Edgar, K.J. Alginate derivatization: A review of chemistry, properties and applications. Biomaterials 2012, 33, 3279-3305. [CrossRef] [PubMed]

2. Lee, K.Y.; Mooney, D.J. Alginate: Properties and biomedical applications. Prog. Polym. Sci. 2012, 37, $106-126$. [CrossRef] [PubMed]

3. Wargacki, A.J.; Leonard, E.; Win, M.N.; Regitsky, D.D.; Santos, C.N.; Kim, P.B.; Cooper, S.R.; Raisner, R.M.; Herman, A.; Sivitz, A.B.; et al. An engineered microbial platform for direct biofuel production from brown macroalgae. Science 2012, 335, 308-313. [CrossRef] [PubMed]

4. Falkeborg, M.; Cheong, L.Z.; Gianfico, C.; Sztukiel, K.M.; Kristensen, K.; Glasius, M.; Xu, X.; Guo, Z. Alginate oligosaccharides: Enzymatic preparation and antioxidant property evaluation. Food Chem. 2014, 164, 185-194. [CrossRef] [PubMed]

5. Tusi, S.K.; Khalaj, L.; Ashabi, G.; Kiaei, M.; Khodagholi, F. Alginate oligosaccharide protects against endoplasmic reticulum- and mitochondrial-mediated apoptotic cell death and oxidative stress. Biomaterials 2011, 32, 5438-5458. [CrossRef] [PubMed]

6. An, Q.D.; Zhang, G.L.; Wu, H.T.; Zhang, Z.C.; Zheng, G.S.; Luan, L.; Murata, Y.; Li, X. Alginate-deriving oligosaccharide production by alginase from newly isolated Flavobacterium sp. LXA and its potential application in protection against pathogens. J. Appl. Microbiol. 2009, 106, 161-170. [CrossRef] [PubMed]

7. Chen, J.; Hu, Y.; Zhang, L.; Wang, Y.; Wang, S.; Zhang, Y.; Guo, H.; Ji, D.; Wang, Y. Alginate Oligosaccharide DP5 Exhibits Antitumor Effects in Osteosarcoma Patients following Surgery. Front. Pharmacol. 2017, 8, 623. [CrossRef] [PubMed]

8. Ertesvag, H. Alginate-modifying enzymes: Biological roles and biotechnological uses. Front. Microbiol. 2015, 6, 523. [CrossRef] [PubMed]

9. Suzuki, H.; Suzuki, K.; Inoue, A.; Ojima, T. A novel oligoalginate lyase from abalone, Haliotis discus hannai, that releases disaccharide from alginate polymer in an exolytic manner. Carbohydr. Res. 2006, 341, 1809-1819. [CrossRef] [PubMed]

10. Lyu, Q.; Zhang, K.; Zhu, Q.; Li, Z.; Liu, Y.; Fitzek, E.; Yohe, T.; Zhao, L.; Li, W.; Liu, T.; et al. Structural and biochemical characterization of a multidomain alginate lyase reveals a novel role of CBM32 in CAZymes. Biochim. Biophys. Acta 2018, 1862, 1862-1869. [CrossRef] [PubMed]

11. Ogura, K.; Yamasaki, M.; Mikami, B.; Hashimoto, W.; Murata, K. Substrate recognition by family 7 alginate lyase from Sphingomonas sp. A1. J. Mol. Biol. 2008, 380, 373-385. [CrossRef] [PubMed]

12. Qin, H.M.; Miyakawa, T.; Inoue, A.; Nishiyama, R.; Nakamura, A.; Asano, A.; Ojima, T.; Tanokura, M. Structural basis for controlling the enzymatic properties of polymannuronate preferred alginate lyase FlAlyA from the PL-7 family. Chem. Commun. 2018, 54, 555-558. [CrossRef] [PubMed]

13. Matsubara, Y.; Kawada, R.; Iwasaki, K.; Kimura, Y.; Oda, T.; Muramatsu, T. Cloning and sequence analysis of a gene (aly PG) encoding poly (alpha-L-guluronate) lyase from Corynebacterium sp. strain ALY-1. J. Biosci. Bioeng. 2000, 89, 199-202. [CrossRef]

14. Wong, T.Y.; Preston, L.A.; Schiller, N.L. Alginate lyaseL: Review of major sources and enzyme characteristics, structure-function analysis, biological roles, and applications. Annu. Rev. Microbiol. 2000, 54, 289-340. [CrossRef] [PubMed]

15. Lombard, V.; Bernard, T.; Rancurel, C.; Brumer, H.; Coutinho, P.M.; Henrissat, B. A hierarchical classification of polysaccharide lyases for glycogenomics. Biochem. J. 2010, 432, 437-444. [CrossRef] [PubMed] 
16. Osawa, T.; Matsubara, Y.; Muramatsu, T.; Kimura, M.; Kakuta, Y. Crystal structure of the alginate (poly alpha-l-guluronate) lyase from Corynebacterium sp. at 1.2 A resolution. J. Mol. Biol. 2005, 345, 1111-1118. [CrossRef] [PubMed]

17. Zhu, B.; Yin, H. Alginate lyase: Review of major sources and classification, properties, structure-function analysis and applications. Bioengineered 2015, 6, 125-131. [CrossRef] [PubMed]

18. Badur, A.H.; Jagtap, S.S.; Yalamanchili, G.; Lee, J.K.; Zhao, H.; Rao, C.V. Alginate lyases from alginate-degrading Vibrio splendidus 12B01 are endolytic. Appl. Environ. Microbiol. 2015, 81, 1865-1873. [CrossRef] [PubMed]

19. Han, F.; Gong, Q.H.; Song, K.; Li, J.B.; Yu, W.G. Cloning, sequence analysis and expression of gene alyVI encoding alginate lyase from marine bacterium Vibrio sp. QY101. DNA Seq. 2004, 15, 344-350. [CrossRef] [PubMed]

20. Zhu, B.; Tan, H.; Qin, Y.; Xu, Q.; Du, Y.; Yin, H. Characterization of a new endo-type alginate lyase from Vibrio sp. W13. Int. J. Biol. Macromol. 2015, 75, 330-337. [CrossRef] [PubMed]

21. Inoue, A.; Anraku, M.; Nakagawa, S.; Ojima, T. Discovery of a Novel Alginate Lyase from Nitratiruptor sp. SB155-2 Thriving at Deep-sea Hydrothermal Vents and Identification of the Residues Responsible for Its Heat Stability. J. Biol. Chem. 2016, 291, 15551-15563. [CrossRef] [PubMed]

22. Chavagnat, F.; Heyraud, A.; Colin-Morel, P.; Guinand, M.; Wallach, J. Catalytic properties and specificity of a recombinant, overexpressed D-mannuronate lyase. Carbohydr. Res. 1998, 308, 409-415. [CrossRef]

23. Yamasaki, M.; Moriwaki, S.; Miyake, O.; Hashimoto, W.; Murata, K.; Mikami, B. Structure and function of a hypothetical Pseudomonas aeruginosa protein PA1167 classified into family PL-7: A novel alginate lyase with a beta-sandwich fold. J. Biol. Chem. 2004, 279, 31863-31872. [CrossRef] [PubMed]

24. Uchimura, K.; Miyazaki, M.; Nogi, Y.; Kobayashi, T.; Horikoshi, K. Cloning and sequencing of alginate lyase genes from deep-sea strains of Vibrio and Agarivorans and characterization of a new Vibrio enzyme. Mar. Biotechnol. 2010, 12, 526-533. [CrossRef] [PubMed]

25. Li, S.; Yang, X.; Zhang, L.; Yu, W.; Han, F. Cloning, Expression, and Characterization of a Cold-Adapted and Surfactant-Stable Alginate Lyase from Marine Bacterium Agarivorans sp. L11. J. Microbiol. Biotechnol. 2015, 25, 681-686. [CrossRef] [PubMed]

26. Huang, L.; Zhou, J.; Li, X.; Peng, Q.; Lu, H.; Du, Y. Characterization of a new alginate lyase from newly isolated Flavobacterium sp. S20. J. Ind. Microbiol. Biotechnol. 2013, 40, 113-122. [CrossRef] [PubMed]

27. Inoue, A.; Takadono, K.; Nishiyama, R.; Tajima, K.; Kobayashi, T.; Ojima, T. Characterization of an alginate lyase, FlAlyA, from Flavobacterium sp. strain UMI-01 and its expression in Escherichia coli. Mar. Drugs 2014, 12, 4693-4712. [CrossRef] [PubMed]

28. Duan, G.; Han, F.; Yu, W. Cloning, sequence analysis, and expression of gene alyPI encoding an alginate lyase from marine bacterium Pseudoalteromonas sp. CY24. Can. J. Microbiol. 2009, 55, 1113-1118. [CrossRef] [PubMed]

29. Miyake, O.; Ochiai, A.; Hashimoto, W.; Murata, K. Origin and diversity of alginate lyases of families PL-5 and -7 in Sphingomonas sp. strain A1. J. Bacteriol. 2004, 186, 2891-2896. [CrossRef] [PubMed]

30. Kim, D.E.; Lee, E.Y.; Kim, H.S. Cloning and characterization of alginate lyase from a marine bacterium Streptomyces sp. ALG-5. Mar. Biotechnol. 2009, 11, 10-16. [CrossRef] [PubMed]

31. Sim, S.J.; Baik, K.S.; Park, S.C.; Choe, H.N.; Seong, C.N.; Shin, T.S.; Woo, H.C.; Cho, J.Y.; Kim, D. Characterization of alginate lyase gene using a metagenomic library constructed from the gut microflora of abalone. J. Ind. Microbiol. Biotechnol. 2012, 39, 585-593. [CrossRef] [PubMed]

32. Huang, G.; Wang, Q.; Lu, M.; Xu, C.; Li, F.; Zhang, R.; Liao, W.; Huang, S. AlgM4: A New Salt-Activated Alginate Lyase of the PL7 Family with Endolytic Activity. Mar. Drugs 2018, 16, 120. [CrossRef] [PubMed]

33. Zhu, B.; Sun, Y.; Ni, F.; Ning, L.; Yao, Z. Characterization of a new endo-type alginate lyase from Vibrio sp. NJU-03. Int. J. Biol. Macromol. 2018, 108, 1140-1147. [CrossRef] [PubMed]

34. Zhu, B.; Hu, F.; Yuan, H.; Sun, Y.; Yao, Z. Biochemical Characterization and Degradation Pattern of a Unique pH-Stable PolyM-Specific Alginate Lyase from Newly Isolated Serratia marcescens NJ-07. Mar. Drugs 2018, 16, 129. [CrossRef] [PubMed]

35. Yagi, H.; Isobe, N.; Itabashi, N.; Fujise, A.; Ohshiro, T. Characterization of a Long-Lived Alginate Lyase Derived from Shewanella Species YH1. Mar. Drugs 2017, 16, 4. [CrossRef] [PubMed]

36. Zhu, X.; Li, X.; Shi, H.; Zhou, J.; Tan, Z.; Yuan, M.; Yao, P.; Liu, X. Characterization of a Novel Alginate Lyase from Marine Bacterium Vibrio furnissii H1. Mar. Drugs 2018, 16, 30. [CrossRef] [PubMed] 
37. Peng, C.; Wang, Q.; Lu, D.; Han, W.; Li, F. A Novel Bifunctional Endolytic Alginate Lyase with Variable Alginate-Degrading Modes and Versatile Monosaccharide-Producing Properties. Front. Microbiol. 2018, 9, 167. [CrossRef] [PubMed]

38. Inoue, A.; Mashino, C.; Uji, T.; Saga, N.; Mikami, K.; Ojima, T. Characterization of an Eukaryotic PL-7 Alginate Lyase in the Marine Red Alga Pyropia yezoensis. Curr. Biotechnol. 2015, 4, 240-248. [CrossRef] [PubMed]

39. Chen, P.; Zhu, Y.; Men, Y.; Zeng, Y.; Sun, Y. Purification and Characterization of a Novel Alginate Lyase from the Marine Bacterium Bacillus sp. Alg07. Mar. Drugs 2018, 16, 86. [CrossRef] [PubMed]

40. Han, W.; Gu, J.; Cheng, Y.; Liu, H.; Li, Y.; Li, F. Novel Alginate Lyase (Aly5) from a Polysaccharide-Degrading Marine Bacterium, Flammeovirga sp. Strain MY04: Effects of Module Truncation on Biochemical Characteristics, Alginate Degradation Patterns, and Oligosaccharide-Yielding Properties. Appl. Environ. Microbiol. 2016, 82, 364-374. [CrossRef] [PubMed]

(C) 2018 by the authors. Licensee MDPI, Basel, Switzerland. This article is an open access article distributed under the terms and conditions of the Creative Commons Attribution (CC BY) license (http:/ / creativecommons.org/licenses/by/4.0/). 